\title{
Effect of soil amendments in relation to soil water retention capacity and soil fertility in maize in alfisol of NSP left canal command area
}

RAJESHWAR MALAVATH AND V. RAMULU

Received : 27.05.2014; Revised : 05.10.2014; Accepted : 22.10 .2014

MEMBERS OF RESEARCH FORUM:
Corresponding author:
RAJESHWAR MALAVATH, Acharya
N.G. Ranga University, A.P. Water
Management Project, A.R.S.
Garikapadu, KRISHNA (A.P.) INDIA

Co-authors :

V. RAMULU, Acharya N.G. Ranga University, A.P. Water Management Project, A.R.S. Garikapadu, KRISHNA (A.P.) INDIA

\begin{abstract}
Summary
On farm the field experiments on effect of soil amendments in relation to soil water retention capacity and soil fertility in maize were taken up in Alfisols of NSP left Canal Command Area during Kharif 2005 and Kharif 2006 at pilot area Ganapavaram of Nagarjuna sagar project left canal command under A.P. Water management project was funded by FAO. The trial was carried with the farmer's participatory mode to study the impact of application of tank silt and farm yard manure as soil amendments in relation to soil water retention capacity and soil fertility and on crop yield of maize. The six treatments consisted of 5t FYM/ha with RDF, 10t FYM/ha with RDF, 10t tank silt/ha with RDF, 20t tank silt/ha with RDF, 30t tank silt/ha with RDF and only RDF. Application of $10 \mathrm{t} F Y M+R D F$ and $10 \mathrm{t}$ of tank silt+ RDF recorded highest grain yield of $6000 \mathrm{~kg} / \mathrm{h}$ and $5500 \mathrm{~kg} / \mathrm{ha}$ during Kharif, 2005 and application of $10 \mathrm{t}$ FYM + RDF and 10t of tank silt + RDF recorded highest grain yield of $6100 \mathrm{~kg} / \mathrm{hand} 5400 \mathrm{~kg} / \mathrm{ha}$ Kharif, 2006, respectively. Post harvest soil analysis revealed that the organic carbon content was high in $10 \mathrm{t} \mathrm{FYM} \mathrm{+} \mathrm{RDF} \mathrm{whereas} \mathrm{the} \mathrm{application} \mathrm{of} \mathrm{increased} \mathrm{tank} \mathrm{silt} \mathrm{recorded} \mathrm{increase} \mathrm{in} \mathrm{water}$ holding capacity during the both the years.
\end{abstract}

Key words : Soil amendments, Soil fertility, Maize, Canal command

How to cite this article : Malavath, Rajeshwar and Ramulu, V. (2014). Effect of soil amendments in relation to soil water retention capacity and soil fertility in maize in alfisol of NSP left canal command area. Asian J. Soil Sci., 9(2): 213216. 